\title{
Pemeriksaan Material pada Pembangunan Rumah Non-Engineered di Daerah Rawan Gempa Dusun Serut, Palbapang Kabupaten Bantul, Yogyakarta
}

\author{
(Material Examination on Construction Non-Engineered Houses in Earthquake Hazard Area, Serut \\ Village, Palbapang Bantul District, Yogyakarta)
}

\author{
MUHAMMAD HERI ZULFIAR
}

\begin{abstract}
Bantul Regency is a region with high level of seismic activity in Indonesia. Buildings that have the highest risk of collapse to earthquake are non-engineered buildings or residential buildings built without planning or not according regulation. This study aims to know contruction practices and material examination on nonengineered buildings in earthquake prone areas in accordance with the Indonesian National Standard. The object research is the construction of non-engineered building in Serut Village, Palbapang, Bantul Regency. The testing of material construction materials include: concrete test, reinforcing steel test and bricks test. the material are tested on the laboratory of Universitas Muhammadiyah Yogyakarta. The observations and measurements to the practices of construction consist of: concrete sloof with size $15 \times 20 \mathrm{~cm}$ with the main reinforcement $4 \varnothing 12$ and beugel reinforcement $\emptyset 6-150$; column with size $10 \times 15 \mathrm{~cm}$ with main reinforcement $4 \varnothing 10$ and beugel reinforcement $\varnothing 6-150$; the concrete mixture is made manually with a composition 1 cement: 3 sand: 2 gravel; Brick size $4.35 \mathrm{~cm}$ x $12.036 \mathrm{~cm}$ x 23.902 cm class criteria M-6 module. Laboratory material test results showed: steel reinforcement diameter $\varnothing 10 \mathrm{~mm}$ obtained tensile strength (fy) $401.52 \mathrm{Mpa}$; 12 mm diameter obtained tensile strength (fy) 393,736 M.Pa; concrete have average compressive strength of $181 \mathrm{~kg} / \mathrm{cm}^{2}$; brick test have average compressive strength of $20.03 \mathrm{~kg} / \mathrm{cm}^{2}$. The conclusion of contruction practices on non-engineered buildings in earthquake prone areas are adequate on major earthquake, the quality of construction concrete and reinforcing steel are fulfilling the criteria and requirements of the Indonesian National Standard, but quality of material brick is not adequate standar.
\end{abstract}

Keywords: Materials, Earthquake, Hazard, Construction Houses, Non Engineered Building

\section{PENDAHULUAN}

Kepulauan Indonesia merupakan wilayah yang memiliki tingkat bencana gempa bumi yang cukup tinggi. Salah satunnya gempa bumi yang terjadi di Yogyakarta dan sekitarnya yang menimbulkan kerusakan bangunan sebanyak 96.790 mengalami kerusakan berat, sebanyak 117,075 mengalami kerusakan sedang, dan sebanyak 156,971 bangunan mengalami kerusakan ringan (BNPB, 2012). Dari peristiwa tersebut dan berdasarkan amanah undangundang 24 (2007) maka diperlukan mitigasi pada daerah rawan gempa khususnya di Kabupaten Bantul dengan tujuan untuk mengurangi tingkat kerusakan struktur bangunan yang rentan terhadap gempa bumi besar dan mengurangi adanya korban jiwa apabila gempa besar terjadi.

Marsell, (2013) menyatakan bahwa kateristik bentuk lahan yang ditinjau berdasarkan aspekaspek geomorfologi memiliki pengaruh berbeda-beda terhadap tingkat keruskan bangunan akibat gempa bumi yaitu aspek morfogenesis yang terdiri atas morfostruktur pasif dan morfodinamik, aspek morfokronologi dan aspek morfoaransemen daerah lereng perbukitan, zona rawan gempa bumi di Kecamatan Pundong, Kabupaten Bantul Yogayakarta berdasarkan pendekatan gemorfologi terdiri atas tiga zona kerawanan 
rendah, zona kerawanan sedang dan zona kerawanan tinggi. Adapun yang dimaksud dengan kerentanan adalah kondisi ketidak mampuan dari keadaan (fisik, sosial, ekonomi, dan lingkungan) terhadap ancaman sesuai dengan level ancaman yang berpengaruh buruk terhadap kondisi tersebut. Kerentanan ditunjukan dengan mengidentifikasi dampak yang terjadi berupa jumlah kerusakan fisik, korban jiwa maupun kerugian ekonomi dalam jangka waktu tertentu yang dapat mengganggu perekonomian akibat trauma maupun kerusakan sumber daya alam lainnya.

Bath (Saputra, 2012) mendefinisikan gempa bumi adalah guncangan di permukaan bumi yang disebabkan oleh pelepasan energi secara tiba-tiba akibat adanya pergeseran batuan kerak bumi di sepanjang zona sesar (subduksi). Energi yang dilepaskan berupa getaran seismic, getaran seismic tersebut dapat dirasakan sebagai gempa bumi setelah mencapai dipermukaan bumi.

Kerentanan bangunan secara teknis disebabkan beberapa faktor, yaitu lokasi/ topografi, penggunaan material dan bentuk bangunan yang kurang sesuai, kualitas dan sistem bangunan yang kurang memadai dengan tingkat kerawanan daerah gempa, kondisi bangunan kurang terawat (Zulfiar, 2014). Selain itu kerusakan bangunan terhadap gempa bumi disebabkan karena bangunan memiliki mutu ketahanan gempa yang sangat rendah, sehingga perlu dilakukan penilaian kualias material konstruksi kerentanan bangunan terhadap gempa dan mitigasi bahaya akibat gempa bumi dari semua jenis bangunan di daerah yang memiliki zona persebaran gempa yang tinggi (Devi dan Naroem, 2015).

Nilai probabilitas kerusakan setiap bangunan berbeda-beda, hal ini disebabkan karena jarak dari pusat gempa, kondisi tanah, topografi, dan jenis tanah yang terdapat dibawah masingmasing bangunan berbeda (Bawono, 2016)

Pada bangunan sederhana seperti rumah 1 tingkat, ternyata dinding menyumbang kekakuan pada struktur dapat dilihat pada hasil perhitungan apabila diberikan beban maka struktur tanpa dinding batu bata mengalami perpindahan sebesar $0,1189 \mathrm{~mm}$ atau lebih besar dibandingkan dengan struktur yang menggunakan dinding batu bata yaitu sebesar 0,0028 mm (Soehanda dkk, 2014).

Material bangunan yang digunakan harus benar-benar baik dan berkualitas, masyarakat harus mengerti tentang dasar-dasar pengujian material bangunan, rumah yang tahan terhadap gempa dan tsunami adalah rumah yang dibangun sebagai satu kesatuan utuh antara pondasi, kolom, dan dindingnya, sehingga bagian-bagian bangunan tidak terlepas saat gempa dan tsunami terjadi (Fitriani, 2014).

Berdasarkan SNI Nomor 1762 (2012) tentang Sistem Konstruksi yang memadai, perlunya sistem konstruksi penahan beban yang memadai supaya suatu bangunan dapat menahan gempa, gaya inersia gempa harus dapat disalurkan dari tiap-tiap elemen struktur kepada stuktur utama gaya horisontal yang kemudian memindahkan gaya-gaya ini kepondasi dan ke tanah.

Berdasarkan SNI Nomor 2052 (2014) tentang perencanaan material baja adalah syarat ukuran tulangan baja untuk material tulangan beton rumah sederhana daerah rawan gempa adalah sebesar tegangan luluh > fy 240 M.Pa.

Selain itu prinsip utama konstruksi tahan gempa meliputi, denah yang sederhana dan simetris, bahan/material bangunan harus seringan mungkin dan sistem konstruksi yang memadai dalam mengurangi resiko gempa (Rinaldi dkk., 2015).

Berdasarkan SNI 1974 (2011) tentang uji kuat tekan beton, mutu beton yang baik untuk kerentanan terhadap bahaya gempa yaitu mutu beton yang lebih dari mutu beton K200.

\section{Rumah Non-Engineered}

Menurut Handayani, (2013), rumah bantuan yang dibangun pasca gempa 2006 di Bantul, Sleman dan Klaten sudah sesuai ketentuan. 180 rumah yang diamati diambil sampel untuk mengetahui luasan dan material konstsuksi. Lebih dari $75 \%$ dari rumah bantuan telah mengalami perubahan berupa penambahan jenis ruang, luas rerata rumah bantuan setelah dilakukan pengembangan adalah $62,5 \mathrm{~m}^{2}$, ukuran ini memenuhi untuk berpenghuni 4 orang dengan standar hunian $9-18 \mathrm{~m}^{2}$ per orang, penambahan ruang untuk kamar tidur, ruang keluarga, dapur dan KM/WC.

Menurut Jayady dkk (2018) pengembangan rumah masyarakat di Yogyakarta umumnya tanpa peran dan pengawasan ahli. Hal ini ditemukan praktik pengembangan atau perluasan rumah tidak sesuai kaidah konstruksi tahan gempa anatara lain detailing tulangan untuk sambungan tidak memedai, penggunaan 
material tidak standar, betuk denah tidak beraturan.

\section{Bangunan Tahan Gempa}

Berdasarkan Berdasarkan SNI 03-1726 (2002) mensyaratkan kriteria kinerja struktur terhadap gempa sebagai berikut:

a. Bila terjadi gempa ringan, bangunan tidak boleh mengalami kerusakan baik pada komponen non-struktural maupun pada komponen strukturalnya.

b. Bila terjadi gempa Sedang, bangunan boleh mengalami kerusakan pada komponen nonstrukturalnya (platfond runtuh, dinding retak) akan tetapi komponen struktural (kolom, balok, sloof) tidak boleh rusak.

c. Bila terjadi gempa besar, bangunan boleh mengalami kerusakan baik pada komponen non-strukturalnya maupun komponen strukturalnya, akan tetapi jiwa penghuni bangunan tetap selamat, artinya sebelum bangunan runtuh masih cukup waktu bagi penghuni bangunan untuk keluar.

\section{Material Konstruksi}

Menurut Wibowo (2015), menyatakan bahwa akibat gempa bumi banyak material sisa bangunan rumah yang masih bisa kita manfaatkan untuk meringankan biaya rekonstruksi, contohnya kuda-kuda kayu, kusen, daun pintu-jendela merupakan contoh material yang mengalami kerusakan tidak terlalu parah saat terjadi gempa, sehingga bisa di daur ulang (re-used)

\section{Metode Penelitian}

\section{Lokasi Penelitian}

Penelitian ini dilakukan pada praktik pembangunan rumah warga Dusun Serut,
Palbapang, Bantul, Daerah Istimewa Yogyakarta.

\section{Pengambilan data dan pengujian benda uji}

Data berupa praktik membangun dilakukan pengamatan, interview mendalam dan melakukan pemeriksaaan sampel benda uji batu bata, campuran beton dan tulangan baja di lokasi penelitian. Pengujian sampel batu bata, beton dan tulangan baja berdasarkan standar pengujian dan dilakukan di laboratorium Teknik Sipil UMY.

\section{Semen}

Berdasarkan SNI 15-2049 (2004) tentang pengertian Semen Portland adalah semen hidrolis yang dihasilkan dengan cara menggiling terak semen portland terutama yang terdiri atas kalsium silikat yang bersifat hidrolis dan digiling bersma-sama dengan bahan tambahan berupa satu atau lebih bentuk kristal senyawa kalsium sulfat dan boleh ditambah dengan bahan tambahan lain. Kandungan udara semen hidrolis mengandung suatu tamabahan udara dalam jumlah yamg tertentu yang menyebabkan udara terkandung didalam mortar didalam batasan

\section{Agregat Halus (Pasir)}

Berdasarkan SNI 03-6820 (2002). Yang dimaksud dengan agregat halus adalah agregat dengan besar butir maksimum 4,76 mm berasal dari alam atau hasil olahan, berikut ini adalah beberapa syarat material pasir (agregat halus) dapat dikatakan berkualitas dan layak pakai menurut SNI 03-6820-2002 yaitu memiliki garasi yang baik, memiliki kadar lumpur yang minimal, Rendahnya kandungan bahan organis, memiliki bentuk potongan pasir yang kuat. Syarat Gradasi untuk adukan dapat dilihat Tabel 1.

TABel 1. Gradasi Agregat untuk Adukan

\begin{tabular}{lcc}
\hline \multicolumn{1}{c}{ Saringan } & \multicolumn{2}{c}{ Persen lolos } \\
\cline { 2 - 3 } & Pasir Alam & Pasir Olahan \\
\hline No. 4 $(4,76 \mathrm{~mm})$ & 100 & 100 \\
No. $8(2,36 \mathrm{~mm})$ & $90-100$ & $95-100$ \\
No.16 $(1,18 \mathrm{~mm})$ & $70-100$ & $70-100$ \\
No. $30(600 \mu \mathrm{m})$ & $40-75$ & $40-75$ \\
No.50 $(300 \mu \mathrm{m})$ & $10-35$ & $20-45$ \\
No.100 $(150 \mu \mathrm{m})$ & $2-15$ & $10-25$ \\
No.200 $(75 \mu \mathrm{m})$ & 0 & $0-10$ \\
\hline
\end{tabular}

Sumber : SNI Nomor 03-6820 Tahun 2002 
Air

Berdasarkan SNI 7974 (2013) persyaratan air pecampur yang dapat digunakan adalah:

a. Air untuk pengadukan (air yang ditimbang atau diukur di batching plan)

b. Air yang ditambahkan oleh operator truk

c. Air bebas pada agregat-agregat dan air yang masuk salam bentuk bahan-bahan tambahan,

d. Air minum boleh digunakan sebagai air pencampur beton tanpa diuji apakah sesuai persyaratan standar ini, dan air es

e. Air pencampur yang seluruh atau sebagian terdiri dari sumber-sumber air yang tidak dapat diminum atau air dari produksi beton boleh digunakan dalam setiap proporsi dengan batasan kualitas yang memenuhi persyaratan.

\section{Agregat kasar (Kerikil)}

Berdasarkan SNI 1969 (2008) Kerikil sebagai hasil disintegrasi 'alami' dari batuan atau berupa batu pecah yang diperoleh dari industri pemecah batu dan mempunyai ukuran butir antara 4,75 mm (No.4) sampai $40 \mathrm{~mm}$ (No. 11/2 inci). Cara penyaringannya adalah campur agregat secara menyeluruh dan kurangilah sampai mendekati jumlah yang diperlukan dengan menggunakan prosedur yang sesuai dengan SNI 13-6717 (2002). Pisahkan semua material yang lolos saringan 4,75 mm (No.4) dengan penyaringan kering, kemudian cuci secara menyeluruh untuk menghialngkan debu atau material lain dari permukaan agregat.

\section{Baja Tulangan Beton}

Berdasarkan SNI 2052 (2014), istilah atau definis baja tulangan beton adalah baja berbentuk batang penampang bundar dengan permukaan polos atau sirip yang digunakan untuk penulangan beton, yang diproduksi dari bahan baku billet dengan cara canai panas (hot rolling), bahan baku yang digunakan berupa billet baja tuang kontinyu untuk baja tulangan beton dan baja profil ringan. Baja Tulangan beton Polos (BjTP) adalah baja tulangan beton berpenampang bundar dengan permukaan rata tidak bersirip. Baja Tulangan beton sirip (BjTS) adalah baja tulangan beton dengan bentuk khusus yang permukaannya memiliki sirip melintang dan memanjang yang dimaksudkan untuk meningkatkan daya lekat guna menahan gerakan membujur dari batang relatif pada beton. Berikut penamaan dan penomoran ukuran baja dan kuat tarik yang diizinkan (dapat dilihat pada Tabel 2).

TABEL 2. Parameter sifat mekanisme baja tulangan beton

\begin{tabular}{|c|c|c|c|c|c|c|c|}
\hline \multirow{2}{*}{$\begin{array}{c}\text { Kelas } \\
\text { baja } \\
\text { tulanga } \\
\text { n }\end{array}$} & \multirow{2}{*}{$\begin{array}{c}\text { Nomor } \\
\text { batang } \\
\text { uji }\end{array}$} & \multicolumn{3}{|c|}{ Uji Tarik } & \multicolumn{2}{|c|}{ Uji lengkung } & \multirow[t]{2}{*}{ TS/YS } \\
\hline & & $\begin{array}{c}\begin{array}{c}\text { Kuat luluh } \\
\text { minimum }\end{array} \\
\begin{array}{c}\mathrm{N} / \mathrm{mm}^{2} \\
\left(\mathrm{kgf} / \mathrm{mm}^{2}\right)\end{array}\end{array}$ & $\begin{array}{c}\begin{array}{c}\text { Kuat tarik } \\
\text { minimum }\end{array} \\
\begin{array}{c}\mathrm{N} / \mathrm{mm}^{2} \\
\left(\mathrm{kgf} / \mathrm{mm}^{2}\right)\end{array}\end{array}$ & $\begin{array}{c}\begin{array}{c}\text { Regangan } \\
\text { minimum }\end{array} \\
\%\end{array}$ & $\begin{array}{c}\text { Sudut } \\
\text { lengkung }\end{array}$ & $\begin{array}{l}\text { Diameter } \\
\text { Pelengkung }\end{array}$ & \\
\hline \multirow[t]{2}{*}{ BJTP 24} & No. 2 & 235 & 380 & 20 & $180^{\circ}$ & $3 \times d$ & - \\
\hline & No. 3 & (24) & (39) & 24 & & & \\
\hline \multirow[t]{2}{*}{ BJTP 30} & No. 2 & 295 & 440 & 18 & $180^{\circ}$ & $\mathrm{d} \leq 16=3 \times \mathrm{d}$ & - \\
\hline & No. 3 & (30) & (45) & 20 & & $d>16=4 \times d$ & \\
\hline \multirow[t]{2}{*}{ BJTS 30} & No. 2 & 295 & 440 & 18 & $180^{\circ}$ & $\mathrm{d} \leq 16=3 \times \mathrm{d}$ & - \\
\hline & No. 3 & (30) & (45) & 20 & & $d>16=4 \times d$ & \\
\hline \multirow[t]{2}{*}{ BJTS 35} & No. 2 & 345 & 490 & 18 & $180^{\circ}$ & $\mathrm{d} \leq 16=3 \times \mathrm{d}$ & - \\
\hline & No. 3 & (35) & (50) & 20 & & $\begin{array}{c}16<\mathrm{d} \leq 40=4 \times \mathrm{d} \\
\mathrm{d}>40=5 \times \mathrm{d}\end{array}$ & \\
\hline \multirow[t]{2}{*}{ BJTS 40} & No. 2 & 390 & 560 & 16 & $180^{\circ}$ & $5 \times \mathrm{d}$ & Min \\
\hline & No. 3 & (40) & (57) & 18 & & & 1,2 \\
\hline \multirow[t]{2}{*}{ BJTS 50} & No. 2 & 490 & 620 & 12 & $90^{\circ}$ & $\mathrm{d} \leq 25=5 \times \mathrm{d}$ & Min \\
\hline & No. 3 & (50) & (63) & 14 & & $d>25=6 \times d$ & 1,2 \\
\hline
\end{tabular}

Sumber : SNI Nomor 2052 Tahun 2014 
TABEL 3. Ukuran standar batu bata

\begin{tabular}{cccc}
\hline Modul & \multicolumn{2}{c}{ Ukuran batu bata $(\mathbf{m m})$} & Panjang $(\mathbf{m m})$ \\
\cline { 2 - 3 } & Tebal & Lebar & \\
\hline M-5A & 65 & 90 & 190 \\
M-5B & 65 & 140 & 190 \\
M-6 & 65 & 110 & 230
\end{tabular}

Sumber : SNI $15-2094-2000$

TABEL 4. Penyimpangan ukuran maksimum dan diperbolehkan

\begin{tabular}{ccccccc}
\hline \multirow{2}{*}{ Kelas } & \multicolumn{6}{c}{ Penyimpangan ukuran maksimum (mm) } \\
\cline { 2 - 7 } & $\mathbf{T}$ & L-5a Dan M-5b & P & T & L & P \\
\hline & 2 & 3 & 5 & 2 & 3 & 5 \\
50 & 2 & 3 & 5 & 2 & 3 & 5 \\
100 & 2 & 3 & 4 & 2 & 3 & 4 \\
150 & 2 & 2 & 4 & 2 & 2 & 4 \\
200 & 2 & 2 & 4 & 2 & 2 & 4 \\
250 & 2 & 2 & 4 & 2 & 2 & 4 \\
\hline
\end{tabular}

\section{Batu Bata}

Pada umumnya batu bata standar batu bata sebagai bahan bangunan yang harus dipenuhi adalah berdasarkan SNI 15-2094 (2000) adalah sebagai berikut:

1) Warna pada penampang belahan (patahan) merata dan dinyatakan dengan warna merah tua muda kekuning-kuningan, kemerah-merahan, dan sebagainya.

2) Bentuk bidang-bidangnya sisinya harus data, rusuk-rusuknya tajam dan siku, permukaan rata dan tidak rusak.

3) Ukuran standar dapat dilihat pada Tabel 3. Untuk penyimpangan ukuran maksmimum batu bata yang diperbolehkan dilihat pada Tabel 4.

4) Kadar Garam

Menurut SNI 15-2094 (2000), standar garam batu bata adalah sebagai berikut : a) Tidak membahayakan bila kurang dari $50 \%$ permukaan bata tertutup oleh lapisan tipis bewarna putih karena pengkristalan garam-garam yang dapat larut.

b) Ada kemungkinan membahayakan bila $50 \%$ permukaan bata tertutup oleh lapisan putih yang agak tebal karena pengkristalan garam-garam yang dapat larut, tetapi bagian-bagian dari permukaan bata tidak menjadi bubuk ataupun terlepas.

c) Membahayakan bila lebih dari $50 \%$ permukaan bata tertutup oleh lapisan putih yang tebal karena pengkristalan garam-garam yang dapat larut dan bagian-bagian dari permukaan bata menjadi bubuk atau terlepas.

Ukuran standar kuat tekan batu bata menurut SNI 15-2094 (2000) dapat dilihat pada Tabel 5

TABEL 5. Standar kuat tekan batu bata

Kelas

Kuat tekan rata-rata dari 10 buah batu bata yang diuji di laboratorium
Koefisien Variasi yang Diizinkan

\begin{tabular}{clc}
\hline 25 & $25 \mathrm{~kg} / \mathrm{cm}^{2}$ & $25 \%$ \\
50 & $50 \mathrm{~kg} / \mathrm{cm}^{2 \mathrm{~s}}$ & $50 \%$ \\
100 & $100 \mathrm{~kg} / \mathrm{cm}^{2}$ & $100 \%$ \\
150 & $150 \mathrm{~kg} / \mathrm{cm}^{2}$ & $150 \%$ \\
200 & $200 \mathrm{~kg} / \mathrm{cm}^{2}$ & $200 \%$ \\
250 & $250 \mathrm{~kg} / \mathrm{cm}^{2}$ & $250 \%$ \\
\hline
\end{tabular}




\section{HASIL DAN PEMBAHASAN}

\section{Praktik-praktik Membangun}

\section{Tahapan perencanaan}

Rumah yang diteliti tidak direncanakan berdasarkan prinsip perencanaan. Hal ini dibuktikan perencanaan tanpa menggunakan Detail Engineering Design (DED), Rencana Anggaran Biaya (RAB) dan spesifikasi teknis. Pembangunan didasarkan pada saran 1 orang berpengalaman pembangunan berdaarkan kebiasaan yang berlaku.

Bentuk bangunan yang diamati oleh peneliti merupakan bentuk bangunan yang baik yang mempunyai bentuk simetris (bujur sangkar) dan mempunyai perbandingan sisi yang baik yaitu panjang < 3 kali lebar, ini dimaksudkan untuk mengurangi gaya puntir yang terjadi pada saat gempa terjadi. Untuk bangunan yang panjang dapat dilakukan pemisahan ruangan (dilatasi) sehingga dapat mengurangi efek gempa dan juga harus diperhatikan bukaan seperti jendela dan pintu tidak boleh terlalu besar. Apabila bukaan itu besar maka akan terjadi pelemahan pada jendela dan pintu tersebut. Karena prinsip utama dasar bangunan tahan gempa adalah setiap komponen struktur bangunan harus terikat dengan kuat satu dengan lainnya, ikatan tersebut mulai dari pondasi dengan sloof, sloof dengan kolom praktis, kolom praktis dengan ring balok, dan ring balok dengan kuda-kuda. Penyelidikan kerusakan akibat gempa menunjukkan pentingnya denah bangunan yang sederhana dan elemen-elemen sturktur penahan gaya horisontal yang simetris. Struktur seperti ini dapat menahan gaya gempa lebih bauk karena efek torsi atau momen puntir dan kekuatannya yang lebih merata. Perlunya sistem konstruksi yang penahan beban yang memadai supaya suatu bangunan dapat menahan gempa, gaya inersia harus dapat disalurkan dari tiaptiap elemen struktur.

\section{Tahap pelaksanaan}

Pembangunan rumah dilaksanakan dengan 1 orang kepala tukang berpengalaman ditambah 5 orang tenaga terampil dan pembantu bangunan dengan 6 hari kerja perminggu. Pembangunan didasarkan berdasarkan arahan lisan mandor dan gambar sketsa dari mulai pondasi sampai dengan atap.

\section{a. Pekerjaan pondasi}

Pada pekerjaan pondasi untuk rumah sederhana ini menggunakan pondasi dangkal berada di tanah yang cukup padat dan keras. Pondasi yang digunakan adalah pasangan batu kali dengan perekat mortar semen (1 : 5). Penggunaan angkur kolom yang ditanam ke pondasi dengan kedalaman $40 \mathrm{~cm}$ dapat dilihat pada Gambar 1.

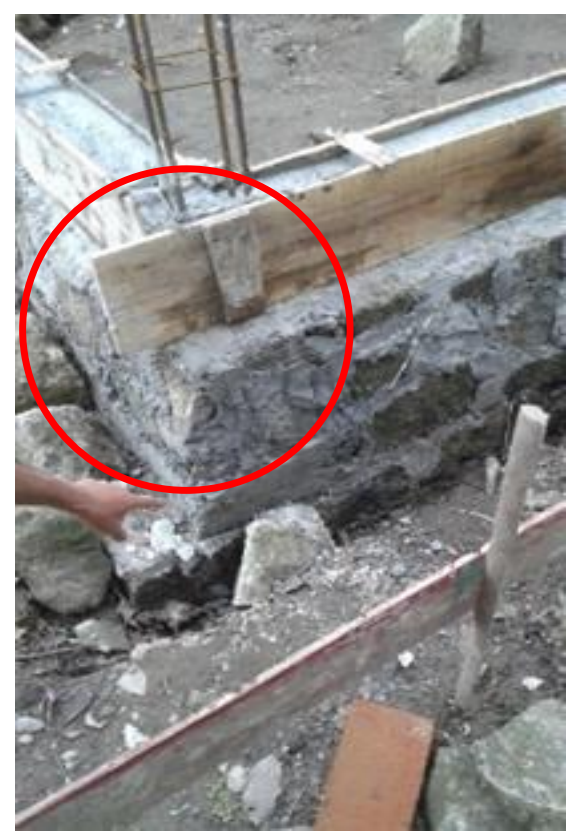

GAMBAR 1. Penggunaan angkur kolom pada pondasi batu kali 


\section{b. Pekerjaan Sloof}

Sloof merupakan struktur dari bangunan yang terletak diatas pondasi dan memiliki fungsi untuk meratakan beban pondasi. Sloof juga mempunyai fungsi sebagai pengunci dinding agar apabila terjadi pergerakan tanah, dinding yang berada diatasnya tidak roboh. Beton sloof yang digunakan pada pembangunan rumah sederhana ini adalah balok beton beton bertulang yang dipasang secara horisontal tepat diatas pondasi batu kali atau batau belah. Ukuran penampang beton sloof rumah 1 lantai menggunakan ukuran penampang $15 \times 10 \mathrm{~cm}$ dan untuk ukuran diameter besi beton yang dipakai sebesar $4 \emptyset 12 \mathrm{~mm}$, sedangkan jarak sengkang sebesar Ø6-150 mm. Adukan an yang digunakan sama dengan beton kolom yaitu sebesar mutu K200. Penyambungan besi tulangan antara sloof bangunan baru dengan bangunan lama diharapakan dapat mengikat atau menghubungkan kedua bangunan tersebut. Namun panjang penyaluran belum memenuhi standar bangunan tahan gempa, dapat dilihat pada Gambar 2.

\section{c. Pekerjaan Kolom Praktis}

Beton kolom adalah balok beton bertulang yang berdiri tegak $90^{\circ}$ pada setiap pertemuan dan sudut pasangan dinding bata. Fungsi kolom adalah memikul beban bangunan yang berada diatasnya. Kolom merupakan suatu elemen struktur tekan yang memegang peranan penting dari suatu bangunan. Ukuran kolom praktis yang digunakan ukurannya sebesar $10 \times 15 \mathrm{~cm}$. Tinggi kolom maksimum untuk rumah sederhana (non-engineered) yang menggunakan dinding sebesar 3 meter. Jika tinggi kolom lebih dari 3 meter maka pada bagian tengah dinding (antara sloof dan ringbalk) diberi balok praktis. Pada rumah yang diteliti ini menggunakan balok praktis setinggi 3 meter. Jarak antar kolom praktis yang dibuat adalah kurang dari 3 meter dengan menggunakan baja tulangan $4 \varnothing 12 \mathrm{~mm}$ untuk begel dan sengkang Ø6-150 $\mathrm{mm}$, dan mutu beton K200, untuk pembesian begel dan sengkang yaitu sudut bengkokan sebesar $135^{\circ}$ dan panjang bengkokan sebesar $\mathrm{L}$ $>10$ Diameter Tulangan. Jarak sengkang sebesar $15 \mathrm{~cm}$, dapat dilihat pada Gambar 3 .



GAMBAR 2. Sambungan sloof dengan bangunan lama

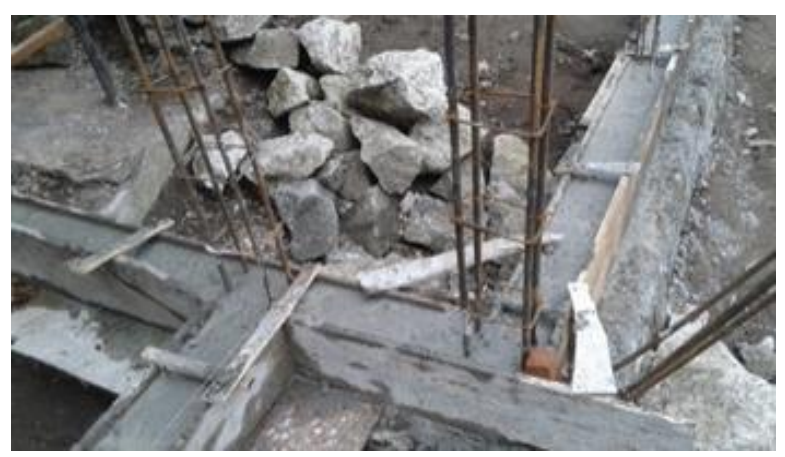

GAMBAR 3. Pembuatan kolom praktis 


\section{d. Pekerjaan Pasangan dinding}

Pada pekerjaan pasangan dinding pada rumah sederhana ini menggunakan pasangan dinding batu bata. Pekerjaan pasangan dinding batu bata dilaksanakan sesudah pekerjaan sloof dan kolom dan dilaksanakan secara bersamaan dengan pekerjaan kolom praktis, sebelum digunakan batu bata terlebih dahulu disiram air hingga jenuh tujuannya agar pori-pori pada batu bata terisi. Pekerjaan plesteran dilakukan pada seluruh pasangan batu bata, beton bertulang dan dinding. Metode peyusunan batu bata diawali dengan pembuatan marking jalur-jalur dinding dua sisi setelah itupada jalur marking serta jalur benang acuan yang telah dipasang pada profil kayu pada ujung bata merah dipasang lapis demi lapis jalur dinding setinggi 1 meter dengan menggunakan adukan pleseran, adukan semen pasir tersebut diaplikasikan secara merata ke permukaan bata merah, kemudian bata merah disusun di atas adukan mortar tersebut sambil terus diperiksa kerataan pasangannya, kemudian bata merah dipukul perlahan sampai mencapai elevasi yang diinginkan. Pekerjaan plesteran dilakukan bersamaan dengan penyelesaian pasangan bata, pemipaan elektrikal, plumbing.

\section{e. Pekerjaan Ring Balk}

Balok praktis/Ring balk adalah balok beton yang dipasang di bagian atas pasaangan dinding. Ukuran penampang balok praktis yang digunakan untuk rumah 1 lantai adalah $10 \times 15$ $\mathrm{cm}$ sama seperti ukuran penampang kolom praktis, dengan ukuran baja tulangan $4 \varnothing 10 \mathrm{~mm}$ dan jarak antar sengkang $\varnothing 6-150 \mathrm{~mm}$, fungsi ring balk adalah meratakan tumpuan beban rangka atap kuda kuda kayu dan meneruskannya ke setiap kolom praktis dan juga mempunyai fungsi mengikat pasangan dinding batu bata, balok praktis.

Berdasarkan hasil pengamatan di lokasi di lokasi penelitian, komposisi pembuatan beton dengan perbandingan $1: 3: 2$ yaitu 1 semen, 3 pasir dan 2 kerikil ditambah air secukupnya kemudian diaduk. Campuran ini dibuat oleh masyarakat setempat dengan harapan mampu mengikat beton lebih baik agar jika terjadi goncangan/gempa struktur betonnya jauh lebih aman. Menurut Mulyati dan Herman (2015) dengan penelitiannya yang berjudul "Komposisi dan Kuat Tekan Beton Pada Campuran Portland Composite Cement, Pasir dan Kerikil", hasil penelitian diperoleh bahwa nilai kuat tekan beton menggunakan perbandingan satu bagian semen, tiga bagian pasir, dan dua bagian kerikil $(1: 3: 2)$ berkisar antara $131,97 \mathrm{~kg} / \mathrm{cm}^{2}-238,2 \mathrm{~kg} / \mathrm{cm}^{2}$, dari hasil penelitian tersebut mutu beton yang didapat termasuk kedalam mutu beton K175 yang dapat digunakan pada pekerjaan pembangunan rumah tinggal, rumah toko, dan jalan rabat beton.

Tahap Pengawasan

\section{Tahap Pengawasan}

Pembangunan rumah tanpa pengawasan tenaga ahli maupun pemerintah setempat. Fungsi pengawasan diserahkan sepenuhnya dengan mandor berdasarkan pengalaman yang dimiliki.

\section{Pengujian Material}

Pengujian material berdasarkan meliputi batu bata, beton dan tulangan baja berdasarkan standar pengujian (SNI) dan dilakukan di laboratorium Teknik Sipil UMY

\section{Pengujian Batu bata}

Hasil pengukuran awal 10 sampel batu bata dengan hasil: rata-rata berat $2,64 \mathrm{~kg}$, panjang $23,90 \mathrm{~cm}$, lebar $12,03 \mathrm{~cm}$, dan tinggi $4,35 \mathrm{~cm}$.

Sebelum pengujian tekan batu bata dilakukan pemotongan dan pelapisan dengan mortar berdasarkan standar pengujian batu bata. Berikut hasil pengukuran 10 sampel benda uji batu bata setelah dipotong dan dilapisi mortar: rata-rata berat $4,01 \mathrm{~kg}$, panjang $11,95 \mathrm{~cm}$, lebar $12,08 \mathrm{~cm}$, tinggi $15,05 \mathrm{~cm}$ dan luas permukaan uji $14.414,02 \mathrm{~mm}^{2}$. Selanjutnya dilakukan pengujian tekan sampel batu bata, hasil pengujian kuat tekan batu bata dapat dilihat pada tabel 6 .

TABEL 6. Hasil uji kuat tekan (peak point) batu bata

\begin{tabular}{ccc}
\hline No & Stress $\left(\mathbf{k g} / \mathbf{m m}^{\mathbf{2}}\right)$ & $\begin{array}{c}\text { Stress } \times \mathbf{1 0 0} \\
\left(\mathbf{k g} / \mathbf{c m}^{\mathbf{2}}\right)\end{array}$ \\
\hline 1 & 0,16121 & 16,12 \\
\hline 2 & 0,19817 & 19,82 \\
\hline 3 & 0,22940 & 22,94 \\
\hline 4 & 0,44444 & 40,0 \\
\hline 5 & 0,25093 & 25,09 \\
\hline 6 & 0,22127 & 22,13 \\
\hline 7 & 0,20961 & 20,96 \\
\hline 8 & 0,22692 & 22,69 \\
\hline 9 & 0,23505 & 23,51 \\
\hline 10 & 0,17254 & 17,25 \\
\hline & Rata-rata & 20,03 \\
\hline
\end{tabular}

Sumber : Analisis hitungan, 2018 
TABEL 7. kuat tekan beton yang telah dikonversi

\begin{tabular}{ccc}
\hline \multirow{2}{*}{ Sampel } & Kuat tekan $(28$ hari) $(\mathrm{MPa})$ & $\times 10 / 0,83\left(\mathrm{~kg} / \mathrm{cm}^{2}\right)$ \\
\hline 1 & 14,6 & 175,90 \\
\hline 2 & 16,30 & 196,385 \\
\hline 3 & 14,186 & 170,91 \\
\hline \multicolumn{3}{c}{ Sumber : Pengujian Lab bahan T. Sipil UMY, 2018 }
\end{tabular}

Berdasarkan Peraturan SII - 0021- 78 dan SKSNI S - 04- 1989- F). Dimensi dari batubata yang diuji di laboratorium sudah memenuhi standar, yaitu dengan dimensi ratarata sebesar Tebal $=4,35 \mathrm{~cm}$, Lebar $=12,036$ $\mathrm{cm}$, Panjang $=23,902 \mathrm{~cm}$ dan kuat tekan rata rata $20,03 \mathrm{~kg} / \mathrm{cm}^{2}$. Dari hasil pengukuran batu bata termasuk batu bata dengan kelas modul M6 dan hasil pengujian tekan tidak memenuhi syarat yaitu kurang dari $25 \mathrm{~kg} / \mathrm{cm}^{2}$.

\section{Pengujian Baja Tulangan}

Pada pembangunan rumah sederhana nonengineered, menggunakan baja tulangan polos diameter $10 \mathrm{~mm}$ dan diameter $12 \mathrm{~mm}$, masing masing panjangnya $70 \mathrm{~cm}$, seluruh hasil pengujian dapat dilihat pada tabel 7 dan grafik semua benda uji tarik baja dapat dilihat pada Gambar 4.

Baja tulangan yang diuji adalah Baja Tulangan Polos (BJTP), yang diambil dari lokasi penelitian digunakan sebagai tulangan geser (sengkang). Dari hasil pengujian didapat nilai rata-rata tegangan leleh baja $\varnothing 10 \mathrm{~mm}$ (fy) 401,52 MPa, dan untuk baja $\varnothing 12 \mathrm{~mm}$ (fy) 393,736 MPa. Dari hasil pengujian tersebut maka baja tulangan yang digunakan di daerah Dusun Serut, Palbapang, Bantul memenuhi kriteria dan syarat dari SNI Nomor 2052 Tahun 2014 dari segi regangan, kuat leleh minimum, kuat tarik minimum, dan layak digunakan sebagai material konstruksi di daerah rawan gempa.

\section{Kubus Beton}

Campuran beton untuk pengujian kubus beton diperoleh dari beton hasil adukan pembangunan di lokasi penelitian. Pengujian kubus beton di lakukan di laboratorium, kemudian dilakukan perhitungan untuk dikonversikan umur beton 28 hari. Hasil uji kuat tekan beton yang telah dikonversi ke silinder beton dengan umur 28 hari dilihat pada tabel 7 .

Berdasarkan Standar Nasional Indonesia Nomor 1974 Tahun 2011. Dari hasil pengujian didapat nilai rata-rata mutu beton sebesar 181 $\mathrm{kg} / \mathrm{cm}^{2}$. Dari hasil pengujian tersebut maka beton yang digunakan sebagai beton K-175 termasuk layak untuk bangunan rumah sederhana di daerah rawan gempa.

\section{KESIMPULAN}

Berdasarkan dari tujuan penelitian telah dilakukan pengamatan praktik konstruksi dan pengujian material konstruksi rumah sederhana terhadap Standar Nasional Indonesia. Berdasarkan analisis yang telah dilakukan dapat kesimpulan sebagai berikut :

a. Bangunan pemukiman di Dusun Serut, Palbapang, Kabupaten Bantul berada di daerah rawan bencana gempa sehingga rawan atau memiliki kerentanan yang cukup tinggi terhadap gempa dan ditemukan praktik-praktik membangun belum sesuai dengan kaidah yang berlaku yaitu tanpa perencanaan, pelaksanaan dan pengawasan yang memadai.

b. Karakeristik material batu bata masuk dalam kriteria modul M-6 dengan kelas 20. Kualitas material batu bata dikelompokkan standar kelas 20, berdasarkan pengujian tersebut batu bata tidak memenuhi standar material konstruksi di daerah rawan gempa.

c. Baja Tulangan Polos yang digunakan untuk tulangan geser, dan utama mempunyai tegangan leleh (fy) di atas 240 $\mathrm{MPa}$. Berdasarkan pengujian tersebut memenuhi kriteria dan syarat ketentuan dari segi regangan, kuat leleh minimum, kuat tarik minimum, dan regangan dan layak digunakan sebagai material konstruksi di daerah rawan gempa. 
d. Pengujian kuat tekan campuran beton pada pembangunan di lapangan masuk katagori mutu beton K-175. Hasil tersebut belum memenuhi kriteria mutu beton untuk kolom dan balok praktis rumah tahan gempa yaitu beton K-200.

\section{DAFTAR PUSTAKA}

Bawono, A.S., (2016), Studi Kerentanan Bangunan Akibat Gempa : Studi Kasus Perumahan Di Bantul, Jurnal Ilmiah Semesta Teknika, 19 (1), 90-97.

Badan Standarisasi Nasional (BSN), (2000), Bata Merah Pejal Untuk Pasangan Dinding, SNI 15-2094-2000. BSN, Jakarta.

Badan Standarisasi Nasional (BSN), (2002), Spesifikasi Agregat Halus untuk Pekerjaan Adukan dan Plesteran dengan Bahan Dasar semen,SNI 03-6820-2002. BSN, Jakarta.

Badan Standarisasi Nasional (BSN), (2002), Standar Perencanaan Ketahanan Gempa Untuk Struktur Bangunan Gedung, SNI 03-1726-2002. BSN, Jakarta.

Badan Standarisasi Nasional (BSN), (2002), Tata Cara Penyiapan Benda Uji dari Contoh Agregat, SNI 13-6717-2002. BSN, Jakarta.

Badan Standarisasi Nasional (BSN), (2004). Semen Portland,SNI 15-2049-2004. BSN, Jakarta.

Badan Standarisasi Nasional (BSN), (2008). Cara Uji Berat Jenis dan Penyerapan Agregat Kasar,SNI 1969: 2008. BSN, Jakarta.

Badan Standarisasi Nasional (BSN), (2011). Cara Uji Kuat Tekan Beton Dengan Benda Uji Silinder,SNI 1974:2011. BSN, Jakarta.

Badan Standarisasi Nasional (BSN), (2012). Tata Cara Perencanaan Ketahanan Gempa Untuk Stuktur Bangunan Gedung dan Non Gedung. SNI 1762:2012. BSN, Jakarta.

Badan Standarisasi Nasional (BSN), (2013). Spesifikasi Air Pencampur yang digunakan dalam Produksi Semen Hidroulis, SNI 7974:2013. BSN, Jakarta.

Badan Standarisasi Nasional (BSN), (2014). Baja Tulangan Beton, SNI 2052:2014. BSN, Jakarta.

Badan Nasional Penanggulangan Bencana (BNPB), (2012). Peraturan Kepala BNPB Nomor 2 Tahun 2012 tentang Pedoman Umum Pengkajian Risiko Bencana, Jakarta.

Devi, K., dan Naroem, N., (2015). Seismic Vulnerability Assessment of Excisting Buildings : It's Importance, International Journal of Innovative Technology and Exploring (IJITEE), 4(9), 39-46.

Fitriani, T.L.S., (2014). The Analysis od Structure Materials in Earthquake and Tsunami Prone Areas in Teluk Palu Seashore, Jurnal Infrastuktur, 4(1), 1521.

Handayani, T., (2013). Model Rekonstruksi Rumah Pasca Gempa di Yogyakarta dan Klaten, Jurnal Arsitektur Komposisi, 10(1), 27-40.

Marsell, R., (2013). Zonasi Daerah Rawan Gempa Bumi Di Kecamatan Pundong, Bantul, Majalah Geografi Indonesia, 27(1), 11-25.

Mulyati dan Herman, (2015). Komposisi dan Kuat Tekan Beton Pada Campuran Portland Composite Cement, Pasir dan Kerikil Dari Beberapa Quarry di Kota Padang, Jurnal Momentum, 17(2), 34-38.

Presiden Republik Indonesia, (2007). Undangundang Republik Indonesia Nomor 24 Tahun 2007 tentang Penanggulangan Bencana, Pemerintah RI, Indonesia.

Rinaldi, Z., Purwatianingsih, A.W., dan Nur'aini, R.D., (2015). Analisa Kontruksi Tahan Gempa Rumah Tradisional Suku Besemah Di Kota Pagar Alam Sumatera Selatan, Seminar Nasional Sains dan Teknologi, 2015, 5(5), 1-10.

Sehonanda, O., Ointu, B.M.M., Tamboto, W. J., dan Pandeleke, R.R., (2014). Kajian Uji Laboratorium Nilai Modulus Elastisitas Bata Merah Dalam Sumbangan Kekakuan Pada Struktur Sederhana, Jurnal Sipil Statik, 1(12), 797-800.

Saputra, A., (2012). Pemetaan Kerentanan Bangunan Temapt Tinggal Tehadap 
Bahaya Gempa Bumi Di Kecamatan Pleret Kabupaten Bantul, Seminar Nasional Teknologi Informasi \& Komunikasi Terapan, Semarang, 23 Juni.

Wibowo, A.P., (2015), Aplikasi Material Bekas Pakai Pada Rekonstruksi Rumah Tinggal Pasca Bencana Alam Gempa Bumi, , 7-8 Oktober 2015,9 (9), 601-606.

Zulfiar, M.H., (2014), Identifikasi faktor Dominan Penyebab Kerentanan Bangunan Di Daerah Rawan Gempa Provinsi Sumatra Barat, Jurnal Ilmiah Semesta Teknika, 17(2), 116-125.

Jayady, A. Zulfiar M.H. dan Saputra N.R.J., (2018), Kerentanan Bangunan Rumah Cagar Budaya terhadap Gempa di Yogyakarta, Jurnal Ilmiah Karkasa, Vo.4, No.1.

PENULIS:

Muhammad Heri Zulfiar

Program Studi Teknik Sipil, Fakultas Teknik, Universitas Muhammadiyah Yogyakarta, D.I Yogyakarta.

Email: herizulfiar@umy.ac.id

zulfiarheri@gmail.com 